\title{
Growth performance of major carps during exposure of zinc and bioaccumulation in fish body organs
}

\author{
Imran Riaz Malik ${ }^{1,5^{*}}$, Sawera Nayyab², Munazza Raza Mirza ${ }^{3}$, Saima Muzammil ${ }^{4}$, Javaria Saleem Cheema², \\ Komal Imran², Kanwal Nisar ${ }^{2}$, Sumreen Hayat ${ }^{4}$, Muhammad Javed ${ }^{5}$ \\ ${ }^{1}$ Department of Biotechnology, University of Sargodha, Sargodha, Pakistan \\ ${ }^{2}$ Department of Biotechnology University of Sialkot, Sialkot, Pakistan \\ ${ }^{3}$ Dr. Panjwani Center for Molecular Medicine and Drug Research, ICCBS, University of Karachi, Karachi, Pakistan \\ ${ }^{4}$ Department of Microbiology, Government College University, Faisalabad, Pakistan \\ ${ }^{5}$ Department of Microbiology, University of Agriculture, Faisalabad, Pakistan
}

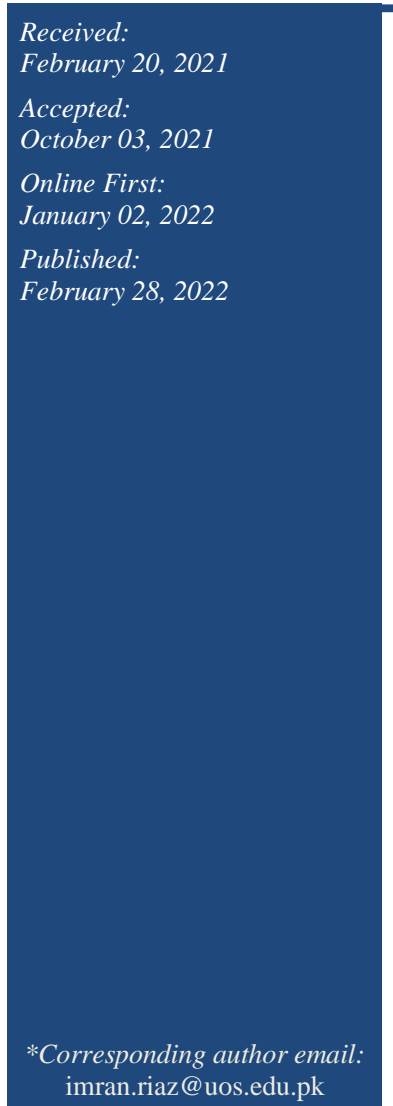

\section{Abstract}

Growth is an index of metals influence on a fish. This investigation aimed to determine growth responses of major carps viz. Catla catla, Labeo rohita and Cirrhina mrigala during exposure to sublethal concentration to zinc. The variations among fish age, species, treatment (zinc) of growth parameters viz. weight increment, fork lengths, and condition factor were statistically significant at $\mathrm{P}<0.01$. The control fish age group 90,120,150 and 180 day showed better feed conversion ratio 0.234 , $0.168,0.132$ and 0.29 as compared to that of zinc exposed fish which showed range 0.01 to 0.23 . Three fish species showed significantly higher amount of zinc in liver than other organs. Labeo rohita showed significantly higher trend for zinc accumulation in body organs than as compared to Cirrhina mrigala and Catla catla. Among body organs; skin, muscle, scales displayed significantly lesser trend for zinc accumulation. It is concluded that metal intoxication significantly reduced the growth of all three fish species and may also show good indicator of metals present in surrounding environment.

Keywords: Bioaccumulation, Chronic sublethal exposure, Heavy metals, Major carps, Zinc

\section{How to cite this:}

Malik IR, Nayyab S, Mirza MR, Muzammil S, Cheema JS, Imran K, Nisar K, Hayat S and Javed M, 2022. Growth performance of major carps during exposure of zinc and bioaccumulation in fish body organs. Asian J. Agric. Biol. 2022(2): 202102092. DOI: https://doi.org/10.35495/ajab.2021.02.092.

This is an Open Access article distributed under the terms of the Creative Commons Attribution 3.0 License. (https://creativecommons.org/licenses/by/3.0), which permits unrestricted use, distribution, and reproduction in any medium, provided the original work is properly cited.

\section{Introduction}

Recent era is well aware about pollution and its effect especially the river pollution with heavy metal is affecting aquatic life badly. Many awareness programs have been started to observe and abatement of river pollution with heavy metal. Discharging of all sorts of highly obnoxious matter into freshwater is an affront to civilized values and damaging sustainability to the environment. In aquatic ecosystem, Fish can be used as an indicator of freshwater pollution through heavy metals as they inhabit diverse tropic levels. Fish absorbs dissolved 
heavy metals from the ambient water that can accumulate in several tissues and organs and even be bio-magnified in the food web. Environmental and health issues resulting from metals present in aquatic ecosystem are very well known (Shah et al., 2020). Decrease in fish species can be linked with industrial and domestic pollutants, ecological degradation and change in habitat in rivers (Atique and An, 2019).

In the absorption procedure, there are four likely ways for the substance (such as metals) to come in a fish; as food ingested, simple circulation of the metals in ionic form over gill pores, drinking water and through skin absorption (Frank et al., 1998; Khan et al., 2018). Most abundant vertebrate are fish which affect human through food intake (Lee et al., 2019). The accumulation of heavy metals is dose and time dependent (Annabi et al., 2013). The trace metals are vital for common physiological procedures; unusually high concentration can be lethal to aquatic organisms (Javed, 2003). The most common pollutants include manganese, Iron, nickel and zinc which are found in Punjab Province Rivers (Javed and Mahmood, 2001). Feed intake and fish productivity decreases in the presence of heavy metals (Sfakianakis et al., 2015). Alvarado et al. (2021) determined the heavy metal concentrations in the organs/tissues of carp and Catfish. Results showed that metal concentrations $(\mathrm{Zn}, \mathrm{Cu}, \mathrm{Cd}$ and $\mathrm{Pb}$ ) were highest in liver whereas metal concentrations ( $\mathrm{Hg}$ and $\mathrm{As}$ ) were highest both in liver and muscle tissue.

Lorenten and Maage (1999) studied the bioaccumulation of trace elements zinc, manganese, iron and copper from first feeding of fingerling of Atlantic salmon (Salmo salar). Selenium become highly toxic when present in high amount in aquatic environment (Li et al., 2020). Zinc, Molybdenum and copper was proved to be the most toxic heavy metals causing increased hazard rate to mortality up to $96 \mathrm{hr}$ and shorter life expectancy (Gouva et al., 2020). Zinc and iron were deposited to body with growth at all stages. High influx of industrial and urban effluents into the Riverine system of Pakistan necessitates the importance to investigate the growth responses of major carps, which are adversely affected due to heavy loads of metals and bioaccumulation of zinc during chronic exposures to suggest measures for the rehabilitation of the aquatic habitats.

\section{Material and Methods}

The research was conducted at Fisheries Research Farms, University of Agriculture, Faisalabad. The experimental organisms were fingerlings major carps viz. Catla catla, Labeo rohita and Cirrhina mrigala starting from the age of 90, 120, 150 and 180 days. Four age groups of three fish species were reared separately for 30-day interval under sub-lethal concentration of zinc with three replications. The fish were kept under laboratory conditions in 500 liter cemented tank for two weeks prior to the experiment. After this acclimatization period, the fish were transferred in 50 liter glass aquaria for growth trials. Five fish of each species were kept in each aquarium containing sublethal concentration of zinc. Chemically pure chloride of zinc $\left(\mathrm{ZnCl}_{2}\right)$ was used to prepare stock solutions for desired dilutions. In control aquarium no metal was added. The condition factors (weight-length relationship) of the fish were examined before starting the experiment. The fish in good state of health, after acclimatization period, were exposed to the following sub-lethal levels of zinc as mentioned (Table 1) for a 30-day growth trial.

Table-1: Concentration of sublethal Zinc (Mg/Litre) after 30 day growth trial

\begin{tabular}{|c|c|}
\hline Species of fish & $\begin{array}{c}\text { Sub-lethal zinc Concentrations } \\
\text { (mg/litre) }\end{array}$ \\
\hline Catla catla & 10.41 \\
\hline Labeo rohita & 13.33 \\
\hline Cirrhina mrigala & 16.67 \\
\hline
\end{tabular}

(Javed and Abdullah, 2003)

\section{Fish growth studies}

Prior to the experiment, initially the growth parameters viz. wet body weight, fork and total length of fingerlings were measured and recorded. After sublethal metal (zinc) exposures of 30-days for each age group, the feed intake, increase or decrease in average weight, length and feed conversion ratios were measured. During each trial, fish was feed to satiation daily (6 days a week) at 9:00 and 17:00 hours with the feed of digestible energy $2.90 \mathrm{Kcal} g$ 1 ( 35 percent digestible protein). 
Condition factors of fish were determined with the following formula:

$$
\mathrm{K}=\frac{\mathrm{W} \times 10^{5}}{\mathrm{~L}^{3}}
$$

Here,

$\mathrm{W}=$ wet weight in gram

$\mathrm{L}=$ wet fork length in millimeter

Number $10^{5}$ is condition factor near the unity (Carlander, 1970)

\section{Determination of Zinc in fish}

A pre-weighed fish body organ samples were transferred to a beaker of $100 \mathrm{ml}$ and concentrated $\mathrm{HNO}_{3}$ of $20 \mathrm{ml}$ was added to it. The beaker was enclosed with a watch glass and low heat was applied on a hot plate until the solid material dissolved. Perchloric acid (72\%) was added @ $10 \mathrm{ml}$ per sample after cooling and heated gently again initially and then vigorously until a clear, colourless solution resulted. When the volume was reduced to about $3 \mathrm{ml}$, cooled and transferred through filter paper to a $50 \mathrm{ml}$ volumetric flask and made up the volume. The filtrate was stored in Teflon bottles for the determination of zinc concentration through Atomic Absorption Spectrophotometer (Perkin Elmer-5100) by following the method as defined in SMEWW (1989).

\section{Statistical analysis}

The data obtained from this experiment, were analyzed statistically using MSTAT software (Nissen, 1989). Analysis of variance was accomplished to find out statistical differences between variables of study.

\section{Results}

Growth performance of three fish species in chronic exposure of the Zinc

The experiment was conducted to observe the growth performance of three fish species includes Catla catla, Labeo rohita and Cirrhina mrigala reared in chronic exposure of zinc at sub-lethal concentrations for four age groups.

\section{i. 90-day fish}

Table 2 represents growth performance of 90-day fish after treatment in comparison of control group. During this trial, Catla catla, Labeo rohita and
Cirrhina mrigala gained the weights of $0.59,1.03$ and $1.05 \mathrm{~g}$ respectively. The average total feed intake by Catla catla was maximum as this fish consumed $66.95 \mathrm{~g}$ feed. Regarding the fork length, the positive increment was found in all three fish species. There was increase in total length in all three fish species with the highest average increment of $0.80 \mathrm{~mm}$ in both Catla catla and Cirrhina mrigala.

Table-2: Growth performance of 90-day fish during chronic exposure of zinc and control for 30 days

\begin{tabular}{|l|c|c|c|c|c|c|}
\hline & \multicolumn{2}{|c|}{ Catla catla } & \multicolumn{2}{c|}{ Labeo rohita } & \multicolumn{2}{c|}{ Cirrhina mrigala } \\
\hline & Treated & Control & Treated & Control & Treated & Control \\
\hline $\begin{array}{l}\text { Survival } \\
\text { rate }\end{array}$ & $100 \%$ & $100 \%$ & $100 \%$ & $100 \%$ & $100 \%$ & $100 \%$ \\
\hline $\begin{array}{l}\text { Weight } \\
\text { (+ or -)(g) }\end{array}$ & 0.59 & 1.12 & 1.03 & 1.78 & 1.05 & 1.38 \\
\hline Feed intake & 66.95 & 91.14 & 51.25 & 91.14 & 47.93 & 91.14 \\
\hline $\begin{array}{l}\text { Feed } \\
\text { conversion } \\
\text { ratio }\end{array}$ & 0.01 & 0.234 & 0.02 & 0.234 & 0.02 & 0.234 \\
\hline $\begin{array}{l}\text { Fork length } \\
\text { (mm) }\end{array}$ & 0.20 & 0.20 & 0.40 & 0.00 & 0.60 & 0.00 \\
\hline $\begin{array}{l}\text { Total length } \\
\text { (mm) }\end{array}$ & 0.80 & 1.40 & 0.60 & 0.60 & 0.80 & 1.00 \\
\hline
\end{tabular}

\section{ii. 120-day fish}

During this trial both Labeo rohita and Cirrhina mrigala gained the average weight of $0.68 \mathrm{~g}$. The total feed intake by Catla catla was maximum by consuming $47.99 \mathrm{~g}$ feed. The fork length increments were similar in both Catla catla and Cirrhina mrigala $(0.60 \mathrm{~mm})$ while in Labeo rohita it was 0.40 $\mathrm{mm}$. However, total length increment was positive in all three fish species with highest increase in total length of $1.80 \mathrm{~mm}$ for Catla catla (Table 3).

Table-3: Growth performance of 120-day fish during chronic exposure of zinc and control for 30 days

\begin{tabular}{|l|c|c|c|c|c|c|}
\hline & \multicolumn{2}{|c|}{ Catla catla } & \multicolumn{2}{c|}{ Labeo rohita } & \multicolumn{2}{c|}{ Cirrhina mrigala } \\
\hline & Treated & Control & Treated & Control & Treated & Control \\
\hline Survival rate & $100 \%$ & $100 \%$ & $100 \%$ & $100 \%$ & $100 \%$ & $100 \%$ \\
\hline $\begin{array}{l}\text { Weight } \\
\text { (+or-)(g) }\end{array}$ & 0.54 & 0.42 & 0.68 & 0.51 & 0.68 & 1.82 \\
\hline Feed intake & 47.99 & 81.67 & 42.71 & 81.67 & 44.23 & 81.67 \\
\hline $\begin{array}{l}\text { Feed } \\
\text { conversion } \\
\text { ratio }\end{array}$ & 0.01 & 0.168 & 0.01 & 0.168 & 0.01 & 0.168 \\
\hline $\begin{array}{l}\text { Fork } \\
\text { length(mm) }\end{array}$ & 0.60 & 0.20 & 0.40 & 0.60 & 0.60 & 2.40 \\
\hline $\begin{array}{l}\text { Total } \\
\text { length(mm) }\end{array}$ & 1.80 & 0.40 & 0.40 & 0.60 & 1.20 & 0.60 \\
\hline
\end{tabular}


Table-4: Growth performance of 150-day fish during chronic exposure of zinc and control for $\mathbf{3 0}$ days

\begin{tabular}{|l|c|c|c|c|c|c|}
\hline & \multicolumn{2}{|c|}{ Catla catla } & \multicolumn{2}{c|}{ Labeo rohita } & \multicolumn{2}{c|}{ Cirrhina mrigala } \\
\hline & Treated & Control & Treated & Control & Treated & Control \\
\hline Survival rate & $100 \%$ & $100 \%$ & $100 \%$ & $100 \%$ & $100 \%$ & $100 \%$ \\
\hline $\begin{array}{l}\text { Weight } \\
\text { (+or-) }(\mathrm{g})\end{array}$ & -2.72 & 0.20 & -1.72 & 0.35 & -1.52 & 0.74 \\
\hline Feed intake & 59.84 & 48.72 & 53.56 & 48.72 & 56.18 & 48.72 \\
\hline $\begin{array}{l}\text { Feed } \\
\text { conversion } \\
\text { ratio }\end{array}$ & -0.04 & 0.132 & -0.03 & 0.132 & -0.03 & 0.132 \\
\hline $\begin{array}{l}\text { Fork } \\
\text { length(mm) }\end{array}$ & 0.00 & 0.20 & -0.20 & 0.20 & 0.00 & 0.20 \\
\hline $\begin{array}{l}\text { Total } \\
\text { length(mm) }\end{array}$ & 0.00 & 0.20 & 0.00 & 0.80 & 0.00 & 0.80 \\
\hline
\end{tabular}

\section{iii. 150-day fish}

A negative growth performance was observed for the three fish species and maximum weight loss was observed in Catla catla i.e. - 2.72 g. The total feed intake was maximum for Labeo rohita by consuming $59.84 \mathrm{~g}$.

Fork length of Catla catla and Cirrhina mrigala did not change while the same for Labeo rohita decrease as $0.20 \mathrm{~mm}$. regarding the total length, there were observed no change in all the three fish species (Table 4).

\section{iv. 180-day fish}

During this growth trial a decline in weight were observed for all the three fish species. The maximum decrease was observed by Catla catla i.e. -1.94 g. Maximum feed consumption was observed by Cirrhina mrigala consuming 98.72 g. Fork length of Cirrhina mrigala did not change while the same for Catla catla and Labeo rohita were -0.60 and -0.20 $\mathrm{mm}$ respectively. Labeo rohita and Cirrhina mrigala did not show change in term of total length gain (Table 5).

Table-5: Growth performance of 180-day fish during chronic exposure of zinc and control for 30 days

\begin{tabular}{|l|c|c|c|c|c|c|}
\hline & \multicolumn{2}{|c|}{ Catla catla } & \multicolumn{2}{c|}{ Labeo rohita } & \multicolumn{2}{c|}{ Cirrhina mrigala } \\
\hline & Treated & Control & Treated & Control & Treated & Control \\
\hline Survival rate & $100 \%$ & $100 \%$ & $100 \%$ & $100 \%$ & $100 \%$ & $100 \%$ \\
\hline $\begin{array}{l}\text { Weight } \\
(+o r-)(g)\end{array}$ & -1.94 & 1.42 & -1.59 & 2.18 & -1.07 & 2.08 \\
\hline Feed intake & 98.44 & 99.11 & 95.17 & 99.11 & 98.72 & 99.11 \\
\hline $\begin{array}{l}\text { Feed } \\
\text { conversion } \\
\text { ratio }\end{array}$ & -0.02 & 0.286 & -0.02 & 0.286 & -0.01 & 0.286 \\
\hline $\begin{array}{l}\text { Fork } \\
\text { length(mm) }\end{array}$ & -0.60 & 1.20 & -0.20 & 0.40 & 0.00 & 0.00 \\
\hline $\begin{array}{l}\text { Total } \\
\text { length(mm) }\end{array}$ & -0.40 & 0.80 & 0.00 & 0.20 & 0.00 & 0.20 \\
\hline
\end{tabular}

Analysis of variance was carried out the difference for growth parameters include weight, fork length, and total length of fish species under chronic exposure to zinc. The results of ANOVA (Table 6) on weight $(\mathrm{g})$ and fork length $(\mathrm{mm})$ showed significant response towards fish species, age and treatment at $\mathrm{p}<0.01$. However for total length $(\mathrm{mm})$ responses were significant towards fish species and age at $\mathrm{p}<0.01$, whereas non-significant for treatment. Most important is that the interaction (species*treatment*age) is strongly significant at the level of 0.01 , which shows that with change in any parameter there were significant differences in growth parameters.

Table-6: Analysis of variance for weight, total length and fork length effected by three fish species of four age groups in control and treated group during chronic exposure to zinc.

\begin{tabular}{|l|c|c|c|c|}
\hline Source of variation & $d f$ & $\begin{array}{l}\text { Weight } \\
\text { Length }\end{array}$ & \multicolumn{3}{|c|}{ Fork Leng } & Total \\
\hline Species & 2 & $178.33^{* *}$ & $413.49^{* *}$ & $572.66^{* *}$ \\
\hline Treatment & 1 & $138.38^{* *}$ & $731.50^{* *}$ & 106.67 \\
\hline Age & 3 & $2033.31^{* *}$ & $3828.02^{* *}$ & $2520.77^{* *}$ \\
\hline Species $\times$ Treatment & 2 & $115.39^{* *}$ & $234.38^{*}$ & 77.90 \\
\hline Species $\times$ Age & 6 & $30.72^{* *}$ & $160.75^{* *}$ & $302.83^{* *}$ \\
\hline Group $\times$ Age & 3 & 7.30 & $82.02^{*}$ & 160.92 \\
\hline $\begin{array}{l}\text { Species } \times \text { Treatment } \\
\times \text { Age }\end{array}$ & 6 & $155.71^{* *}$ & $519.47^{* *}$ & $753.93^{* *}$ \\
\hline Error & 216 & 7.79 & 25.73 & 103.90 \\
\hline
\end{tabular}

**Significant at the level of 0.01 , *Significant at the level 0.05

Condition factor for three fish species during these trials varied significantly at the level of 0.01 . The interaction (species $\mathrm{x}$ age) was significant at the level of 0.01 also. Condition factor for 180-day zinc exposed fish was 2.326 while the same lowest was 2.009 for 90 -day fish (Table 7).

Table-7: Analysis of variance on condition factors $(K)$ of three fish species under chronic exposure of zinc.

\begin{tabular}{|c|c|c|c|c|}
\hline S.O.V. & $\begin{array}{c}\text { Mean } \\
\text { square }\end{array}$ & S.E. & F. Value & Probability \\
\hline Fish species & 0.849 & 0.0266 & 30.0614 & $\mathrm{p}<0.01$ \\
\hline Fish age & 0.575 & 0.0307 & 20.3469 & $\mathrm{p}<0.01$ \\
\hline $\begin{array}{c}\text { Fish species } \\
\text { ×Fish age }\end{array}$ & 0.339 & 0.0531 & 12.0153 & $\mathrm{p}<0.01$ \\
\hline Treatment & 0.045 & 0.0217 & 1.6016 & N.S \\
\hline Error & 0.028 & & & \\
\hline
\end{tabular}




\section{Accumulation of metal in body organs of fish}

Table 8 displays zinc accumulation patterns in body organs of three fish species during growth trials for four age groups.

\section{i. 90-day fish}

During 30-day trial liver was the organ which showed significantly highest accumulation of zinc as $835.00,1100.00,756.25 \mathrm{ug} \mathrm{g}^{-1}$ in Catla catla Labeo rohita and Cirrhina mrigala correspondingly. As far as the mean accumulation of zinc in all three fish species was concerned Labeo rohita displayed the maximum average accumulation $(477.87 \pm 384.12 \mathrm{ug}$ $\left.\mathrm{g}^{-1}\right)$. The differences among all the fish species were statistically significant (Table 8).

Table-8: Accumulation of zinc (ug per gm) in three fish species during chronic exposure

\begin{tabular}{|c|c|c|c|}
\hline \multirow{2}{*}{$\begin{array}{c}\text { Fish } \\
\text { organs }\end{array}$} & Catla catla & Labeo rohita & $\begin{array}{c}\text { Cirrhina } \\
\text { mrigala }\end{array}$ \\
\cline { 2 - 4 } & \multicolumn{4}{|c|}{ 90-day fish } \\
\hline Gills & 193.02 & 318.97 & 176.15 \\
\hline Kidney & 481.90 & 803.57 & 686.36 \\
\hline Liver & 835.00 & 1100.00 & 756.25 \\
\hline Skin & 150.80 & 166.27 & 242.24 \\
\hline Muscle & 65.08 & 174.54 & 219.81 \\
\hline Scales & 125.73 & 303.85 & 356.36 \\
\hline $\begin{array}{c}\text { Mean } \\
\pm \text { S.D. }\end{array}$ & $308.59 \pm 296.02 \mathrm{c}$ & $477.87 \pm 384.12 \mathrm{a}$ & $406.19 \pm 252.21 \mathrm{~b}$ \\
\hline \multicolumn{5}{|c|}{$\mathbf{1 2 0 - d a y}$ fish } \\
\hline Gills & 190.24 & 304.72 & 462.88 \\
\hline Kidney & 243.10 & 483.55 & 669.01 \\
\hline Liver & 1313.10 & 515.50 & 1105.66 \\
\hline Skin & 182.64 & 111.15 & 271.97 \\
\hline Muscle & 115.07 & 113.70 & 128.96 \\
\hline Scales & 116.37 & 286.88 & 314.37 \\
\hline $\begin{array}{c}\text { Mean } \\
\pm \text { S.D }\end{array}$ & $360.09 \pm 469.40 \mathrm{~b}$ & $302.58 \pm 173.58 \mathrm{c}$ & $492.14 \pm 352.28 \mathrm{a}$ \\
\hline
\end{tabular}

Means values with similar letters indicates statistical similarity at the level of 0.05 .

\section{ii. 120-day fish}

Both liver and kidney appeared as organs for maximum zinc accumulation while the same were minimum for muscle in three fish species. Cirrhina mrigala of this age group showed maximum tendency for zinc accumulation (Table 8).

\section{iii. 150-day fish}

Liver of 150 day Labeo rohita showed the highest accumulation of zinc $\left(1834.53 \mathrm{ug} \mathrm{g}^{-1}\right)$. The muscle of all three fish species shows the lowest levels of zinc accumulation. However, the mean accumulation patterns in three fish species varied significantly with the highest concentration $\left(594.01 \pm 722.32 \mathrm{ug} \mathrm{g}^{-1}\right)$ of Labeo rohita (Table 9).

\section{iv. 180-day fish}

Catla catla and Cirrhina mrigala were the species that showed maximum accumulation of zinc in liver while kidney of Labeo rohita appeared as organ that concentrate maximum zinc as $793.62 \mathrm{ug} \mathrm{g}^{-1}$. However, fish muscle showed minimum accumulation of zinc as $130.50,96.19,46.08 \mathrm{ug} \mathrm{g}^{-1}$ in Cirrhina mrigala, Labeo rohita and Catla catla correspondingly (Table 9).

Table-9: Zinc Accumulation (ug per gm) in three fish species under chronic exposure

\begin{tabular}{|c|c|c|c|}
\hline \multirow{2}{*}{$\begin{array}{c}\text { Fish } \\
\text { organs }\end{array}$} & Catla catla & Labeo rohita & $\begin{array}{c}\text { Cirrhina } \\
\text { mrigala }\end{array}$ \\
\cline { 2 - 4 } & \multicolumn{3}{|c|}{ 150-day fish } \\
\hline Gills & 165.78 & 164.30 & 162.80 \\
\hline Kidney & 625.64 & 1126.13 & 716.50 \\
\hline Liver & 1011.90 & 1834.53 & 1329.00 \\
\hline Skin & 190.33 & 167.44 & 422.50 \\
\hline Muscle & 98.11 & 126.42 & 138.54 \\
\hline Scales & 297.80 & 145.22 & 425.44 \\
\hline $\begin{array}{c}\text { Mean } \\
\text { 土S.D. }\end{array}$ & $398.26 \pm 353.76$ & $594.01 \pm 722.32$ & $532.46 \pm 443.56$ \\
\hline \multicolumn{5}{|c|}{$\mathbf{1 8 0 - d a y ~ f i s h ~}$} \\
\hline Gills & 159.86 & 215.28 & $\mathrm{~b}$ \\
\hline Kidney & 397.45 & 793.62 & 512.82 \\
\hline Liver & 1286.65 & 610.83 & 1023.10 \\
\hline Skin & 148.23 & 113.73 & 199.58 \\
\hline Muscle & 46.08 & 96.19 & 130.50 \\
\hline Scales & 122.56 & 185.93 & 153.86 \\
\hline $\begin{array}{c}\text { Mean } \\
\pm \text { SD }\end{array}$ & $360.14 \pm 469.02$ & $335.93 \pm 292.90$ & $364.79 \pm 352.24$ \\
\hline
\end{tabular}

Means values with similar letters indicates statistical similarity at the level of 0.05 .

\section{Discussion}

During the course of the experiments three fish species in the treated group showed a reduction in their growth at all age groups in comparison to the control. Fish growth was found reduced significantly in Nile tilapia when exposed to sublethal concentration of Zinc (Abdel-Tawwab et al., 2016). Heavy metal intoxication was found to results in toxic impacts and ecological damages (Moon et al., 2019). Feed intake and fish productivity decreases in the presence of heavy metals (Sfakianakis et al., 
2015). The adrenergic responses consequences in the raise of circulating adrenaline which organizes the body for exercise by increasing ventilation rate, cardiac output and blood flow to muscle, and mobilizing substrates aimed at aerobic metabolism, and second common reaction to stress is the reduced growth. Perhaps this is not surprising that metals can cause reduction in growth (Elling et al., 1999). Cirrhina mrigala and Labeo rohita showed better growth performance when compared with fish of all four age groups i.e. Catla catla showed higher sensitivity towards zinc contamination as far as growth performance is concerned. khanom et al. (2020) studied muscular tissue bioaccumulation of heavy metals including $\mathrm{Pb}, \mathrm{Cd}, \mathrm{Cr}, \mathrm{Zn}, \mathrm{Cu}$ and $\mathrm{Mn}$ in two fish species (Gudusia chapra and Eutropiichthys $v a c h a$ ) and found that $\mathrm{Zn}$ was at a higher quantity, while $\mathrm{Cd}$ at a lower amount in both species in Padma River.

During chronic exposure to zinc for all trials, bioaccumulation of zinc occurred maximum in liver for all fish age group except 180-day Labeo rohita and lowest concentration of zinc observed in muscle and as described by Zhao et al that higher accumulation of metals in liver related to its function of metabolism that required to maintain life (Zhao et al., 2012), which is in confirmatory to following results. Abdel-Tawwab et al. (2016) also found that Zinc was found maximum in liver and kidney which was lowest in muscle. Alvarado et al. (2021) determined the heavy metal concentrations in the organs/tissues of Carp and Catfish cultured in Lake Chapala and found that liver had a higher concentrating capacity for $\mathrm{Zn}, \mathrm{Cu}, \mathrm{Cd}$ and $\mathrm{Pb}$ were highest in liver and muscle tissue. According to Bervoets et al. (2001) concentrations of zinc, lead, copper, and cadmium was measured in food, water, sediment, and Gasterosteus aculeatus tissues. Metal accumulation level in tissues was associated to the levels in water, sediment and food whereas gill/liver showed highest metal accumulation as compared to muscle.

\section{Conclusion}

Regarding metal toxicity, Zinc affect growth parameters (weight increment, fork lengths and condition factors) significantly $(\mathrm{P}<0.01)$. The control fish showed better feed conversion ratio as compared to that of zinc exposed fish. Liver showed significantly higher tendency to Zinc accumulation and significantly least trend in muscle than other organs of three fish species. Labeo rohita showed significantly higher trend to accumulation of zinc in body organs followed Cirrhina mrigala and Catla catla. It is concluded that metal intoxication significantly reduced the growth of all three fish species and may also show good indicator of metals present in surrounding environment.

\section{Acknowledgement}

Authors are grateful to the Fish Farm Manager, University of Agriculture, Faisalabad for providing land and resources to carry out this research work.

\section{Disclaimer: None.}

\section{Conflict of Interest: None.}

Source of Funding: None.

\section{References}

Abdel-Tawwab M, El- Sayed GO and Shady SH, 2016. Growth, Biochemical Variables, and Zinc Bioaccumulation in Nile Tilapia, Oreochromis Niloticus (L) as Affected by Water Born Toxicity and Exposure Period. Int. Aquat. Res. 8: 197-206.

Alvarado C, Cortez-Valladolid DM, Herrera-Lopez EJ, Godinez X and Ramirez JM, 2021. Metal Bioaccumulation by Carp and Catfish Cultured in Lake Chapala, and Weekly Intake. Appl. Sci. 11: 6087.

Annabi A, Said K and Messoudi I, 2013. Cadmium: bioaccumulation, histopathology and detoxifying mechanisms in fish. Am. J. Res. Commun. 1: 6079.

Atique U and An KG, 2019. Reservoir water quality assessment based on chemical parameters and the chlorophyll dynamics in relation to nutrient regime. Polish. J. Stud. 28: 1043-1061.

Bervoets L, Blust R and Verheyen R, 2001. Accumulation of Metals in the Tissues of Three Spined Sticklebacks (Gasterosteus Aculeatus) from Natural Fresh Waters. Ecotoxicol. Environ. Saf. 48: 117-127.

Carlander DK, 1970. Handbook of Fresh Water Fisheries Biology. Vol. 1. The Iowa State University Press. Iowa, USA.

Elling CE, Thirstrup K, Holst B and Schwartz TW, 1999. Conversion of Agosit Site to Metal-Ion 
Chelator Site in the Beta (2)-Adrenergic Receptor. Proceed. Natl. Acad. Sci. USA. 96: 12322-12327.

Frank APCG, John BW, Ronald WR and Haffner GD, 1998. Mechanism of biomagnification in fish under laboratory and field conditions. Environ. Sci. Technol. 33: 133-141.

Gouva E, Nathanailides C, Skoufos I, Paschos I, Athanassopoulou F and Pappas I, 2020. Comparative study of the effects of heavy metals on embryonic development of Zebrafish. Aquat. Res. 51(8): 3255-3267.

Javed M and Abdullah S, 2003. Studies on Growth and Bio-energetics of fish under heavy metal toxicity. First Annual Report, PSF Project No 62: 29, Ministry of Science and Technology, Govt. of Pakistan, Islamabad (unpublished data).

Javed M and Mahmood G, 2001. Metal Toxicity of Water in a Stretch of River Ravi from Shahdera to Baloki Headworks. Pak. J. Agric. Sci. 38(1-2): 3742.

Javed M, 2003. Relationships among Water, Sediments and Plankton for the Uptake and Accumulation of Heavy Metals in the River Ravi. Int. J. Pharmacol. Sci. 2(4): 326-331.

Khan N, Atique U, Ashraf M, Mustafa A, Mughal MS, Rasool F, Azmat H, Tayyab M and Iqbal KJ, 2018. Effect of various protein feeds on the growth, body composition, hematology and endogenous enzymes of catfish (Pangasius hypophthalmus). Pak. J. Zool. Suppl. Ser: 112-119.

Khanom DA, Nesa A, Jewel MAS, Haque MA, Paul AK, Iqbal S, Atque S and Alam L, 2020. Muscular tissue bioaccumulation and health risk assessment of heavy metals in two edible fish spcies (Gudusia chaptra and Eutropiichthys vacha) in Padma River, Bangladesh. Punjab Uni. J. Zool. 35(1): 81-89.

Lee JW, Choi H, Hwang UK, Kang JC, Kang YJ, Kim KI and Kim JH, 2019. Toxic Effects of Lead Exposure on Bioaccumulation, Oxidative Stress, Neurotoxicity, and Immune Response in Fish: A Review. Environ. Toxicol. Pharmacol. 68: 101-108.

Li MY, Gao CS, Du XY, Zhao L, Niu XT, Wang GQ and Zhang DM, 2020. Effect of Sub-Chronic Exposure to Selenium and Astaxanthin on Channa Argus: Bioaccumulation, Oxidative Stress and Inflammatory Response. Chemosphere. 244: 125546.
Lorenten M and Maage A, 1999. Trace Elements Status of Juvenile Atlantic Salmon Salmo Salar Fed a Fish Meal Based Diet With or Without Supplementation of Zinc, Iron, Manganese and Copper from First Feeding. Aquac. Nutr. 5: 163-171.

Moon WK, Atique U and An KG, 2019. Ecological risk assessments and eco-toxicity analysis using chemical, biological, physiological responses, DNA damages and gene-level biomarkers in Zebrafish (Danio rerio) in an urban stream. Chemosphere. 239: 124754.

Nissen O, 1989. User guide to MSTAT-C. Micro Computer Statistical Program. Michigan State University, USA.

Sfakianakis DG, Kentouri PM and Tsatsakis AM, 2015. Effect of heavy Metals on fish larvae deformities: A review. Environ. Res. 137: 246255.

Shah N, Khan A, Ali R, Marimuthu K, Nazir Uddin M, Rizwan M, Rahman KU, Alam M, Adnan M, Jawad SM, Hussain $S$ and Khisroon $M$, 2020. Monitoring Bioaccumulation (in Gills and Muscle Tissues), Hematology, and Genotoxic Alteration in Ctenopharyngodon idella Exposed to Selected Heavy Metals. BioMed. Res. Int. 2020, 16.

SMEWW, 1989. Standard Methods for the Examination of Water and Wastewater. (17 $7^{\text {th }}$ Ed.). A.P.H.A., Washington DC, USA.

Zhao S, Feng C, Quan W, Chen X, Niu J and Shen Z, 2012. Role of living environments in the accumulation characteristics of heavy metals in fishes and crabs in the Yangtze River Estuary, China. Mar. Pollut. Bull. 6(64): 1163-1171.

\section{Contribution of Authors}

Malik IR: Performed research work, data collection, data analysis and manuscript write up Nayyab S, Cheema JS, Imran K \& Nisar K: Helped in editing and write up of manuscript Mirza MR, Muzammil S \& Hayat S: Helped in editing of manuscript and literature review Javed M: Conceived the idea and designed research methodology 